\title{
European Journal of
}

\section{Technology}

(EJT)

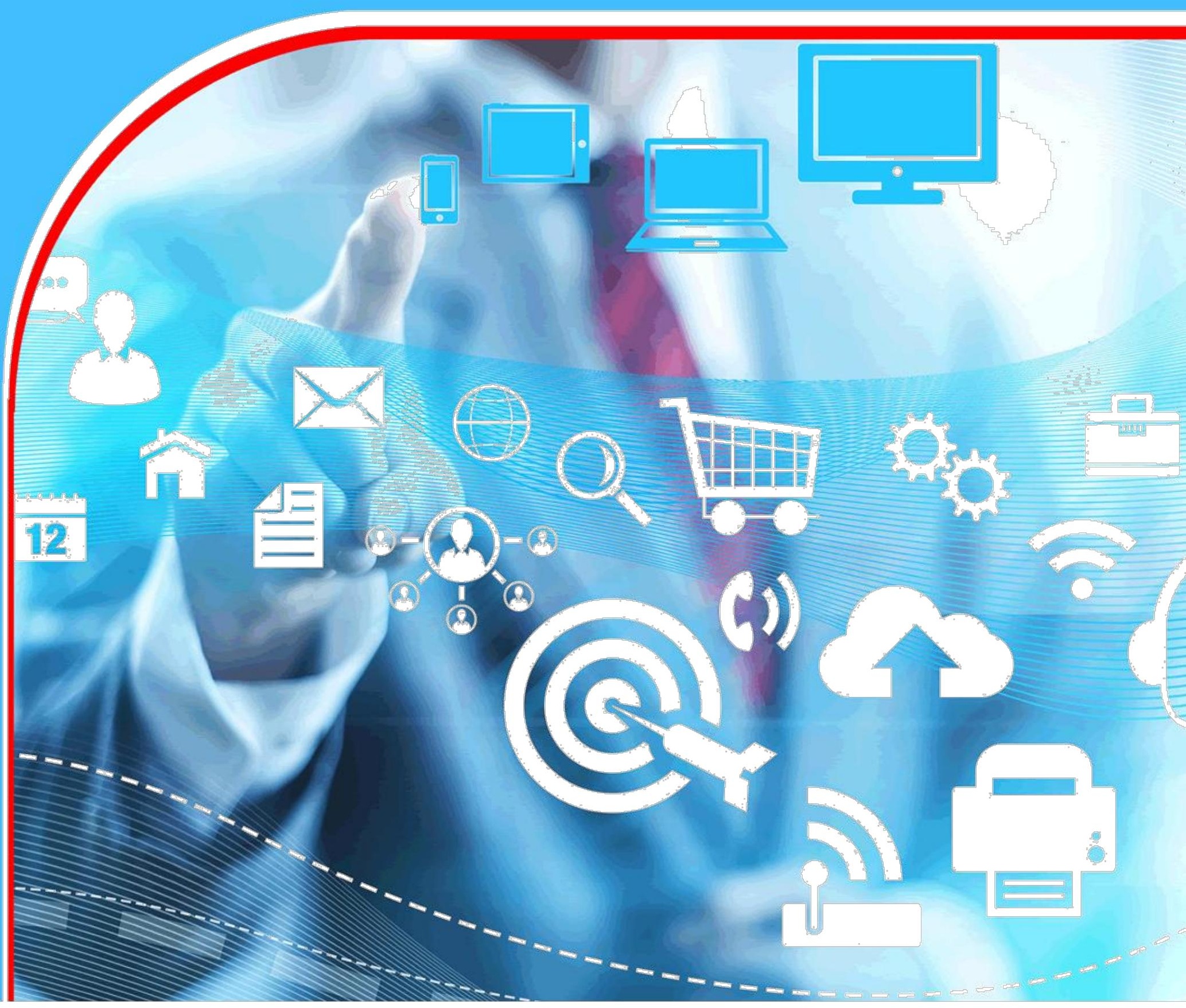

EFFECTIVE UTILIZATION OF ICT RESOURCES AND ICT CAPABILITIES IN SAUDI ARABIA HIGHER INSTITUTES

Hany Mohamed Hassan El-Hoby and Dr. Adamu Abobakar Ibrahim 


\title{
EFFECTIVE UTILIZATION OF ICT RESOURCES AND ICT CAPABILITIES IN SAUDI ARABIA HIGHER INSTITUTES
}

\author{
${ }^{1 *}$ Hany Mohamed Hassan El-Hoby \\ *Corresponding Author's Email: elhoby@gmail.com \\ ${ }^{2}$ Dr. Adamu Abobakar Ibrahim \\ Co- Author's Email: Adamu@gmail.com
}

\begin{abstract}
Purpose: The research aims to identify the reality of the contribution of information and communication technology to keep pace with the educational trends that adopt call to the quality of performance and improving the educational system with a view to the composition of the forces of human, economic growth and social council, and contribute to the building of civilization on the basis of racial superiority and discrimination.
\end{abstract}

Methodology: The study used a quantitative research method in order to uncover the problems of the effective utilization of information technology in learning in private colleges.

Results: The Ministry of Higher Education in Saudi Arabia has always been working closely with Saudi Universities to improve the quality of higher education to ensure that university graduates have the skills and learning outcomes. Saudi's young student generation needs to acquire new skills and capabilities to meet the current diversification objectives and to be competitive with the best students from anywhere in the world. This study proposed effective framework to ensure that acceptable quality educational standards are fulfilled in private colleges. Saudi's young student generation needs to acquire new skills and capabilities to meet the current diversification objectives and to be competitive with the best students from anywhere in the world. This study proposed effective framework to ensure that acceptable quality educational standards are fulfilled in private colleges. This study will focus on Information and Communication Technologies (ICT) resources and capabilities.

Unique contribution to theory, practice and policy: This study can contribute in both empirical study and theoretical approach to understand the effective utilization of ICT in higher educational institutional

Keywords: Effective utilization / ICT resources, ICT capabilities, higher institutes 


\subsection{INTRODUCTION}

Information technology is an important and influential in the success of the institutions of education, including increasing the absorptive capacity of learners and the spread of knowledge. 'in order to education institutions to provide educational structure effective, after it realized the role of information technology in the educational process, to answer the following questions: What is the extent of the need of the educational process of information technology?, and their effects on education?, and what is the added value of information technology and educational institutions compared to the cost?. This is to make the educational institutions match with the requirements of the information age, and the needs and desires of the labor market.

Information and communication technology (ICT) is an indispensable part of the contemporary world. In fact, culture and society have to be adjusted to meet the challenges of the knowledge age. The pervasiveness of ICT has brought about rapid technological, social, political, and economic transformation, which has eventuated in a network society organized around ICT (Castells, 1996).

One of the main objectives of this study is to identify the obstacles faced by the Saudi higher education institutions when applying management philosophy information technology in education. It is noted in the UNESCO reports that Arab countries are divided into rich countries and poor ones. Given that poverty is a key partner in the killing of Education and people searching for a living, so there is no creativity in poor countries, but we can find the poor researcher is being created, when there is a new environment for creativity. Information Technology plays an important role in innovation (UNESCO Institute for Statistics, 2009). This paper proposes a Trusted Platform to ensure accuracy and confidentially in field of education aligning with technology.

\subsection{Background of the Study}

The Ministry of Higher Education in Saudi Arabia has always been working closely with Saudi Universities to improve the quality of higher education to ensure that university graduates have the skills and learning outcomes that are in line with international standards and job market requirements (Smith \& Abouammoh, 2013).

The Saudi higher education working to increase competition and the operation of an 'educational market' in which the role of government is minimised is more likely to achieve quality outcomes for the Saudi higher education system (Christensen, 2011; Jacobs and van der Ploeg, 2006; Steier, 2003).Within this context, this study has an ambitious project to assess the learning outcomes in education. The assessment of learning outcomes is particularly important to the Kingdom higher educational institutes. The Kingdom has recognized the need to move from a natural resource-based economy to a knowledge-based economy, which puts new priority on the role of universities.

Saudi's young student generation needs to acquire new skills and capabilities to meet the current diversification objectives and to be competitive with the best students from anywhere in the world. Mazi and Altbach (2013) Private institutions are increasingly part of the global higher education landscape. Indeed, private higher education is the fastest growing sector in higher education worldwide. 


\subsection{Problem Statement}

Leask and Younie (2013) draws attention of researchers to understanding of educator's quality and to acknowledged it as a basic variable in instructive results, based on the fact that little consideration is paid to enhancing the nature of instructors' expert information. Crucial to this is crevices in use and results of ICT asset usage for education around the world. Some of these holes might be clarified as far as educators' advanced proficiency, which is an intricate idea (Krumsvik, 2008). Onasanya at al. (2010) He affirmed that most tertiary organizations instructors in Nigeria need satisfactory pedagogical learning for powerful usage of ICT assets for educating. There is by all accounts a hole in the reasonable abilities particularly as respects the ICT assets usage skills in the present educating. Okwudishu (2005) and Gambari and Okoli (2007) found that the non-accessibility of some ICT assets in schools hamper instructors usage of ICT assets in educating.

Currently in KSA, both resources \& capabilities in higher institution are in abundance. The effectiveness of information systems and how those characteristics contribute to the development and improvement of the internal processes of the organization and to improve human relations and service employees, customers and managers under the open system is flexible and achieve strategic goals. Fifty-sixth Issue (Riyadh: Public Administration and Information Studies $1437 \mathrm{H}$ ). There is lack in research on the issues raised in the above mentioned areas. Twenty-Fifth Issue (Riyadh: Public Administration and Information Studies $1424 \mathrm{H})$. Crucial to this is state of effective utilization of ICT resources \& capabilities which the above mentioned also neglected.

\subsection{Objectives}

The research aims to identify the reality of the contribution of information and communication technology to keep pace with the educational trends that adopt call to the quality of performance and improving the educational system with a view to the composition of the forces of human, economic growth and social council, and contribute to the building of civilization on the basis of racial superiority and discrimination.

1. To understand the impact of mediator variable on effective utilization of ICT resources and ICT capabilities in higher institution.

2. To examine the effective utilization of ICT resources \& ICT capabilities of higher institution.

3. To investigate the impact of effective utilization of ICT resources and ICT capabilities on higher institution.

\subsection{Research Questions}

The following research questions are proposed:

1. What are the (mediator) variables dominated in effective utilization of ICT resources \& ICT capabilities in higher institution?

2. What are the (independents) dominant antecedent's process in effective utilization of ICT resources \& ICT capabilities in higher institution?

3. How could each dimension of the conceptual model contribute meaningfully in effectively utilization of ICT resources \& ICT capabilities?

4. 


\subsection{THEORETICAL BACKGROUND}

This section establishes the theoretical background in which the forthcoming discussion and analysis is based. DeLone and McLean Information Systems Success model has been adopted as the basis theory for this research. This come from the fact the theory gains a huge support for information system success. Effective Utilization from this research point of view is a "success" thus, for ICT resources and Capabilities for higher Education to be successful there have to be effectively utilized.

Another updated success model, which interprets the model in its original context, is a causal exploratory model of how perceived quality affects use and user satisfaction, which are direct antecedents of net benefits (Bernroider, 2008). The focus is on assessing net benefits via assessment of the positive and negative impacts of the system. The dimension "Intention to use/use and user satisfaction" was omitted from the model because it is not seen as a fitting dimension of success unless system use is voluntary.

Zaied, (2012) proposes another integrated model for evaluating IS success (see Figure 4). It is aimed at supporting decision makers in organizations on evaluating the implementation of information systems. Consequently, ten dimensions were proposed for measuring information system success: Behavior intention; Information quality; Management support; Perceived ease of use; Perceived usefulness; Service quality; System quality; Training; User satisfaction; and User involvement.

\subsection{Conceptualization and Developed Hypothesis}

One of the important parts of the research process involves the conceptualization of research constructs. Conceptualization is the process of taking a construct and refining it by giving it a conceptual or theoretical definition (Neuman, 2006). A construct is thus a conceptual term used to describe a phenomenon of theoretical interest (Nunnally, 1978) or "an element of scientific discourse that serves as verbal surrogates for phenomenon of interest" (Edwards \& Bagozzi, 2000).

\subsection{ICT Resources in Higher Institutions}

Information technology is an important and influential tool in the success of the institutions of education, and it is increasing the absorptive capacity of learners and the spread of knowledge (Mikre, 2011). Information technology resources involves computer hardware (computers, storage devices, printers, and other peripherals); computer software (operating systems, programming tools, utilities, applications, and internal software development); computer services (information technology consulting, computer and network systems integration, web hosting, data processing services, and other services); communications services (voice and data communications services) and wired and wireless communications equipment.

Resources that falls within this wide scope are classified under ICT resources and houses hardware components that forms the tangible agents that provides physical layers for users, software systems that presents logical layers to the hardware in use, communication mediums that transfers resources across clustered associations, Networks and development tools that avails an option for re-introducing new options (Tashkandi \& Al-Jabri, 2015). Human expertise that provides intellect layer to supplement the right usage of these resources can be qualified under this classification and considered as an important ICT resource component. Likewise, ICT data, which users intra-and-inter-depend on, stands countable as another 
component within this ICT scope (Ismail et al., 2012). Thus, the following hypotheses were formulated:

\section{H1: ICT resources is positively associated with Management Support}

H1a: ICT resource Accessibility is positively associated with Management Support

H1b: ICT resource Stability is positively associated with Management Support

H1c: ICT resource Functionality is positively associated with Management Support

H1d: ICT resource Interoperability is positively associated with Management Support

\section{H2: ICT resources is positively associated with Training}

$\mathrm{H} 2 \mathrm{a}$ : ICT resource Accessibility is positively associated with Training

$\mathrm{H} 2 \mathrm{~b}$ : ICT resource Stability is positively associated with Training

H2c: ICT resource Functionality is positively associated with Training

H2d: ICT resource Interoperability is positively associated with Training

\section{H3: ICT resources is positively associated with User Involvement}

H3a: ICT resource Accessibility is positively associated with User Involvement

H3b: ICT resource Stability is positively associated with User Involvement

H3c: ICT resource Functionality is positively associated with User Involvement

H3d: ICT resource Interoperability is positively associated with User Involvement

\subsection{ICT Capabilities in Higher Institutions}

This research uses the term "Information technology capabilities" to refer to human capabilities on utilization of ICT in the educational process. Thus, the study tries to focus on the factors of effective utilization of IT resources and capabilities in higher education (Faiz \& Al-Mutairi, 2015). The nature and scope of ICT capability is not fixed, but is responsive to ongoing technological developments. This is evident in the emergence of advanced internet technology over the past few years and the resulting changes in the ways that students construct knowledge and interact with others (Al-Adhaileh \& Al Fridan, 2015). Students develop capability in using ICT for tasks associated with information access and management, information creation and presentation, problem-solving, decision-making, communication, creative expression and empirical reasoning.

This includes conducting research, creating multimedia information products, analyzing data, designing solutions to problems, controlling processes and devices, and supporting computation while working independently and in collaboration with others (Xanthidis et al., 2016). Students develop knowledge, skills and dispositions around ICT and its use, and the ability to transfer these across environments and applications. They learn to use ICT with confidence, care and consideration, understanding its possibilities, limitations and impact on individuals, groups and communities (Tashkandi \& Al-Jabri, 2015).

\section{H4: ICT Capabilities has a significant effect on Management Support}

H4a: Availability of IT/IS service has a significant effect on Management Support

H4b: Improved Level of Service has a significant effect on Management Support

H5: ICT Capabilities has a significant effect on Training 
European Journal of Technology

ISSN 2520-0712 (Online)

Vol.2, Issue 2 No.1, pp1-16, 2017

H5a: Availability of IT/IS service has a significant effect on Training

H5b: Improved Level of Service has a significant effect on Training

\section{H6: ICT Capabilities has a significant effect on User Involvements}

H6a: Availability of IT/IS service has a significant effect on User Involvements

H6b: Improved Level of Service has a significant effect on User Involvements

\subsection{Management Support}

Management support is adopted from Zaied, (2012) integrated Delone and McLean model as a mediating factor of system and service quality of DeLone and McLean model. It is refers to management approval and continuous support not only during the IS project implementation but also throughout the operational phase of the system. This research conceptualized it to mediated both ICT resource and capabilities and effective utilization relationship. Previous studies use it as a measure of: management's encouragement; providing all necessary resources; discussing problems associated with the system; appreciating the optimal use of the system; and having sufficient knowledge of the system (Ngai, et al., 2004; Tashkandi \& Al-Jabri, 2015) Consistent with these previous work this research aims to evaluates ICT resources and capabilities. Therefore, the following hypothesis is formulated:

H7: Management Support is positively associated with Effective utilization of ICT resources and capabilities

\subsection{Training}

Training is also adopted from Zaied, (2012) integrated Delone and McLean model as a mediating factor of system and service quality of DeLone and McLean model. This variable is determining the level of training an organization's employees undergo with respect to information systems. Thus it should have a positive relationship with implementation success. This research conceptualized it to mediated both ICT resource and capabilities with effective utilization relationship. Previous research uses it as: training programs on the application; the clearance of training programs; users' role; availability of training material; and support (Bradford and Florin, 2003; Al-Adhaileh \& Al Fridan, 2015). In order to further from these previous works, this study is adopting training to evaluate the effective utilization of ICT resources and capabilities. As a result, it is conceptualized to mediate the relationship between ICT resources and capabilities with Effective Utilization. Therefore the following hypothesis is formulated:

H8: Training is positively associated with Effective utilization of ICT resources and capabilities.

\subsection{User Involvement}

User involvement is also adopted from Zaied, (2012) integrated Delone and McLean model as a mediating factor of system and service quality of DeLone and McLean model. This variable is determining user involvement as a matter of importance and personal relevance that users attach to a given system (Zaied, 2012). This research conceptualized it to mediate both ICT resource and capabilities with effective utilization relationship. Previous research studies select user involvement measures as: user's involvement in input design; user's involvement in output design; perceptions of service evaluations; perceived value; and customer attitude (Larsen \& Sorebo , 2007; Faiz, \& Al-Mutairi, 2015). Consistent with these 
previous works, this study is adopting user involvement to evaluate effective utilization of ICT resources and capabilities. . Therefore the following hypothesis is formulated:

H9: User Involvement is positively associated with Effective utilization of ICT resources and capabilities

\subsection{Effective Utilization of ICT Resources and ICT Capabilities}

ICT as a global reference for educations is an umbrella that encompasses many aspects of computing, communications and technologies. Many people interchangeably understand ICT as IT, Information Technology, which is defined by the Information Technology Association of America (ITAA), as the study, design, development, implementation, support or management of computer-based information systems, particularly software applications and computer hardware (OKolocha \& Nwafani, 2015). It is therefore deal with the use of electronic computers and computer software to convert, store, protect, process, transmit and retrieve information, securely.

In terms of infrastructural layout, findings indicate that most-higher institutions within Saudi Arabia do have the ICT resources and scholars at least have knowledge of their existence (Alsuraihi et al., 2016). This is also confirmed by higher institution's bid to incorporate ICT policies that implements the availability, usage and maintenance of such resources (Croteau et al., 2015). These resources achievable assisting meeting various institutions' educational goals through development of teaching materials like class notes, teaching guides and aids, development of lab materials for practical lessons etc for learners by lecturers through use of computing resources and associated peripherals (Alsuraihi et al., 2016). Contents management through provision of secure storage facilities provides guarded access to such information (OKolocha \& Nwafani, 2015). Contents disseminations where computing software is used to design and develop teaching materials and hardware components like audio-visual hardware are used to aid in teaching purposes. Fourthly, contents examinations for students by giving out tests and examinations through tools like webCT hence mark and grade them (Umar et al., 2015).

\subsection{PROFILE OF THE RESPONDENTS}

When we study the information system sciences the researcher is attempt to describe personnel characteristics of respondents, they have very significant role to play in expressing and giving the responses about the problem, because the participate factors in the conceptual model is one of the information system success (Saldaña, 2015). keeping this in mind, in this study a set of confidential data which anyone of our respondents giving us is determine the success of this work, this characteristics namely, age group, gender, academic qualification, current Position, the name of institution etc. of the 215 respondents have been examined and presented in this chapter of effective utilization of ICT resources and ICT capabilities of respondents have very significant role to play in determine and giving the responses about the problem. 
European Journal of Technology

ISSN 2520-0712 (Online)

Vol.2, Issue 2 No.1, pp1-16, 2017

\subsection{Profile of Respondents by Current Position in Your Institution}

Table 1: Distribution of Current Position in Your Institution

\begin{tabular}{|l|l|l|l|l|}
\hline \multirow{7}{*}{ valid } & Position & Frequency & Valid Percent & Cumulative Percent \\
\cline { 2 - 6 } & Lecturer & 67 & 31.2 & 31.2 \\
\cline { 2 - 6 } & $\begin{array}{l}\text { Assistant } \\
\text { Professor }\end{array}$ & 73 & 34 & 65.1 \\
\cline { 2 - 6 } & $\begin{array}{l}\text { Associate } \\
\text { Professor }\end{array}$ & 24 & 11.2 & 76.3 \\
\cline { 2 - 6 } & Professor & 23 & 10.7 & 87.0 \\
\cline { 2 - 6 } & Others & 28 & 13 & 100.0 \\
\hline Total & & 215 & & \\
\hline
\end{tabular}

Table 1 shows the sample test of the study are $(\mathrm{N}=215)$, in terms of distribution of existing effective utilizing, $31.2 \%$ were in agree as lecturer, while $34 \%$ were in strongly agree as assistance professor. This means a lecturer and assistant professor has appreciate the utilizing technology in education process and qualified to use technology rather than those as associate professor were $11.2 \%$ and professors were $10.7 \%$.

\subsection{Profile of Respondents by Gender}

Table 2 shows the sample test of the study are $(\mathrm{N}=215)$, provided demographic information. The majority of the academic staff surveyed were male $(82.8 \%)$, meaning $(17.2 \%)$ of the academic staff surveyed were female. In terms of response of existing effective utilizing research in kingdom of Saudi Arabia. The researcher have a big number of males because the general policy of gender segregation. Although the sexes are segregated on campus. For example, the King Fahd University for Petroleum and Minerals in Dammam, which is a male-only university, and Princess Nora bint Abdulrahman University in Riyadh, which is a female-only university.

There are agencies have responsibility for the implementation of education policy: the Ministry of Education, the General Presidency of Girls' Education, with primary responsibility for the segregated education of girls and women. (Smith, L., \& Abouammoh, A., 2013).

\section{Table 2: Distribution of Gender}

\begin{tabular}{|l|l|l|l|l|}
\hline & Gender & Frequency & Valid Percent & Cumulative Percent \\
\hline valid & Male & 178 & 82.8 & 82.8 \\
\hline & Female & 37 & 17.2 & 100 \\
\hline Total & & 215 & & \\
\hline
\end{tabular}




\subsection{Profile of Respondents by Age Group}

Table 3 shows Of the 215 respondents provided demographic information. The majority of the academic staff surveyed were (20-29) years old is $(15.8 \%),(30-39)$ years old is $(34 \%)$, (40-49) years old is (34.4\%), and (above 50) years old is (15.8\%). So according the academic qualification and nationality are the highest concern about effective utilizing ICT resources and capabilities, unless the high level qualifications, means professors are a little in Saudi universities because of they are searching about the ranking.

Table 3: Distribution of Age Group

\begin{tabular}{|l|l|l|l|l|}
\hline & Age group & Frequency & Percent & Cumulative Percent \\
\hline valid & $20-29$ & 34 & 15.8 & 15.8 \\
\hline & $30-39$ & 73 & 34 & 49.8 \\
\hline & $40-49$ & 74 & 34.4 & 84.2 \\
\hline & Above 50 & 34 & 15.8 & 100 \\
\hline Total & & 215 & & \\
\hline
\end{tabular}

So those are lowest concern want to undergo a training program on the use of technology, or they are did not have the management support to have the efficiency utilize the ICT in their institute. Or they did not involve in ICT activities to develop their capabilities. In terms of response of existing effective utilizing research in kingdom of Saudi Arabia.

\subsection{Profile of Respondents by Academic Qualification}

Table 4 shows the sample test of the study are $(\mathrm{N}=215)$ respondents provided demographic information. The majority of the academic staff surveyed were bachelor degree $(20.9 \%)$. the academic staff surveyed were master degree $(23.3 \%)$. the academic staff surveyed were doctoral degree (55\%), because of the lowest number of PHD Saudi qualification, they have more non-Saudi PHD according the Ministry of Higher Education in 2009-2010 (Smith \& Abouammoh, 2013). SO it's meaning the highest qualifications degree are interesting with technology, so they are seeking to develop himself and maybe undergo a training program on the use of technology and therefore know its importance in their work. In terms of response of existing effective utilizing research in kingdom of Saudi Arabia.

Table 4: Distribution of Academic Qualification

\begin{tabular}{|l|l|l|l|l|}
\hline & academic qualification & Frequency & $\begin{array}{l}\text { Valid } \\
\text { Percent }\end{array}$ & $\begin{array}{l}\text { Cumulative } \\
\text { Percent }\end{array}$ \\
\hline valid & Bachelor & 45 & 20.9 & 20.9 \\
\hline & Master & 50 & 23.3 & 44.2 \\
\hline & PHD & 120 & 55.8 & 100.0 \\
\hline Total & & 215 & & \\
\hline
\end{tabular}

\subsection{Profile of Respondents by Nationality}

Table 5 shows the sample test of the study are $(\mathrm{N}=215)$ respondents provided demographic information. The majority of the academic staff surveyed were Saudi nationality is $(18.1 \%)$, meaning the non-Saudi nationality is (81.9). According the big number of non-Saudi respondents in the research because of, the Ministry of Higher Education in 2009-2010 shows, the great majority of the enrolments with only 13,650 students $(1.80 \%)$ enrolled in 
master's and doctoral degrees. Women comprise around $25 \%$ for masters and doctoral degrees offered within the country. With the greatest concentration at the Ph.D. level where they represent over $19 \%$ of all enrolments. So the Saudi universities should be ask non-Saudi qualification join to sharing in his renaissance rather than efficiency (Smith \& Abouammoh, 2013).

Table 5: Distribution of Nationality

\begin{tabular}{|l|l|l|l|l|}
\hline & Nationality & Frequency & Valid Percent & Cumulative Percent \\
\hline valid & Saudi & 39 & 18.1 & 18.1 \\
\hline & Non Saudi & 176 & 81.9 & 100 \\
\hline Total & & 215 & & \\
\hline
\end{tabular}

So it's meaning the higher institutes in Saudi Arabia kingdom are seeking the academic staff which they have high ICT capabilities and qualifications to involve technology in educational process, so they are seeking to develop the learning output to insure applying the high qualified techniques in education, and to applying the criterion of accreditation and quality In terms of the research problem which, effective utilizing ICT resources and ICT capabilities in Saudi higher institutes.

\subsection{RESEARCH FINDINGS}

The new model of IS presented new understanding on how academic staff in the Saudi Arabia higher institution evaluate the effective utilization of ICT resources and ICT capabilities. The effective utilization IS model with two dimensions ICT resources and ICT capabilities has important influence which could contribute to realistic use to information technology resources involves computer hardware (computers, storage devices, printers, and other peripherals); computer software (operating systems, programming tools, utilities, applications, and internal software development); computer services (information technology consulting, computer and network systems integration, web hosting, data processing services, and other services); communications services (voice and data communications services) and wired and wireless communications equipment (it means hardware, software, database and network).

Therefore this chapter address the answer of the research questions, question 1 is: What are the (mediator) variables dominated in effective utilization of ICT resources \& ICT capabilities in higher institution? The answer is: The three factors, management support, training and user involvement are the main dependent constructs for the proposed model the constructs produced high loadings ranging in measuring the impact of effective utilization of ICT resources \& ICT capabilities in higher institution in Saudi Arabia. There are two factors of these three namely management support and training have discriminant and directly influence in ICT resources. And all of those factors are directly influence in ICT capabilities. So these construct are represented in the proposed conceptual model. The second question is: What are the (independents) dominant antecedent's process in effective utilization of ICT resources \& ICT capabilities in higher institution? The answer is: The four factors of ICT resource of the proposed model namely accessibility, stability, functionality and improbability are inter-construct variables. These constructs are represented the impact of effective utilization of ICT resources in higher institution in Saudi Arabia. The two factors of ICT capabilities of the proposed model namely availability of IS/IT services and improve 
level of performance are inter-construct variables. These constructs are represented the impact of effective utilization of ICT capabilities in higher institution in Saudi Arabia.

So these inter construct are represented in the proposed conceptual model. The last question is: How could each dimension of the conceptual model contribute meaningfully in effectively utilization of ICT resources \& ICT capabilities? The answer is: the finding of the research study of 215 respondents is answered to this question where the construct produced high loadings measures. Therefore, indicating adequate factors within the proposed model.

\subsection{DISSUCSSION}

Based on research findings the researcher found that the information technology theories by Delon and Muclin (2002) and Bernoried (2008) and integrated IS by Zaied (2012) has shown in this research. The researcher informs the quality of information and services of the information systems are is the base of success system. The literature review based on Bernoried integrated information success (2008) proposed some variable the proposed model adapted two of this (functionality and interobaility). The conceptual model proposed four inter- construct (assessability, stability, functionality and interobability) as ICT resources construct. This is ICT resources shown in the research findings as a behavior of information system success are influence in the information system successes.

Tallon and Kraemer (2007) lament the lack of robust of research on IT capabilities, the conceptual model proposed two inter- construct (availability of IT/IS and improve level of performance) as ICT capabilities construct. This is ICT capabilities shown in the research findings as a behavior of human are influence in the information system successes. According the previous studies, Carr (2003) proposed the resources alone do not explain the difference of firm's competitiveness, and according Teece's (1997) proposed dynamic capabilities assets as the source of competitive advantage. Based on Saudi Arabia review some studies proposed the academic staff unless should be have a knowledge of ICT resources and the policies of implement usag to acheiveable of educational goal (Alsuraihi et al., 2016: Croteau et al., 2015: Alsuraihi et al., 2016). So the conceptual proposed model prove the ICT resources and ICT capabilities are the one of important in the information system success.

According to integrated IS by Zaied (2012), he proposed management support, training and user involvement to supporting decision makers in organizations on evaluating the implementation of information systems, the researcher adapted the three construct to inform to a policy maker believe that there is reason in effectiveness use. The policy makers will understand that be successful for investment. So the research findings shown the three construct has a positively influence in the information system success. So the six dimensions are formed to make a new conceptual information system model.

\subsection{RECOMMENDATIONS FOR FUTURE RESEARCH}

Taking the opinions of a random sample of academic staff in Saudi Arabia institutes for this survey, we suggest to more develop the vision to the effectiveness utilizing of ICT resources and ICT capabilities because of a huge developing area of future technology and the uses in all fields. We mentioned earlier that there exists a gap in using ICT in classroom and there is a shortage in training to academic staff (Ageel, 2011; Al Mulhim, E., 2014; Al-Madani \& Allaafiajiy, 2014). Others suggest that Saudi Arabian universities must improve their ICT infrastructure, including the provision of suitable connection networks and formal training of 
staff in utilizing ICT resources (Alturise et al., 2016). On the other side there are researcher proposed that there is a lack of ICT policy and strategy, lack of proper infrastructure and access to ICT resources and lack of management roles (Albugarni \& Ahmed, 2015). Therefore, agencies for quality and accreditation of academic units helped to facilitate the application of quality educational policies in Saudi Arabia. Educational quality system leads to an improved standard and good management of facilities (Alarifi, 2015; Alsoliman, 2015).

\subsection{CONTRIBUTION}

The study proposed a new model to evaluate the effective utilization of IT Resources \& capabilities. Productive disposition occurs when a policy maker views the effective utilization of ICT resources and ICT capabilities are useful and worthwhile. The research findings were mastered that investment in technology not the only to achieve the quality or the goals, then a policy maker must believe that there is reason in effectiveness use. There are contributions from the policy maker themselves. The policy makers should understand that be successful for investment (kilpatrick et al., 2001)

\section{REFERENCES}

Ad, A. B. Y., T, A. B., \& Ghazi, M. E. L. (2012). Cloud computing: security challenges, 2631.

Ageel, M. (2011). The ICT proficiencies of university teachers in Saudi Arabia: A case study to identify challenges and encouragements. Hummingbird, (2), 55-60.

Al Mulhim, E. (2014). The barriers to the use of ICT in teaching in Saudi Arabia: A review of literature. Universal Journal of Educational Research, 2(6), 487-493.

Al-Adhaileh, M., \& Al Fridan, A. (2015, October). A Flexible Distance Education Delivery Model: Design and Implementation at King Faisal University. In e-Learning (econf), 2015 Fifth International Conference on (pp. 312-315). IEEE.

Alarifi, S. A. (2015). The Quality of Saudi Accreditation Standards for Distance Learning: Benchmarking And Expert Validation.

Al-Madani, F. M., \& Allaafiajiy, I. A. (2014). Teachers' professional development on ICT use: A Saudi sustainable development model. Journal of Modern Education Review, 4(6), 448-456.

Alsoliman, B. S. (2015). A strategic approach to the implementation of quality distance learning in Saudi Arabia: an embedded case study (Doctoral dissertation, University of Salford).

Alsuraihi, M. D., Yaghi, K., \& Nassuora, A. B. (2016). Knowledge Sharing Practices Among Saudi Academics: A Case Study Of King Abdulaziz University. Journal of Current Research in Science, 4(1), 63. 
Alturise, F., Calder, P. R., \& Wilkinson, B. (2016, July). A comparison of ICT infrastructure in Saudi Arabian and Gulf states universities. In SAI Computing Conference (SAI), 2016 (pp. 764-769). IEEE.

Bernroider, E. W. (2008). IT Governance for Enterprise Resource Planning Supported By the Delone-Mclean Model of Information Systems Success. Information \& Management, 45(5), 257-269.

Bradford, M., \& Florin, J. (2003). Examining the role of innovation diffusion factors on the implementation success of enterprise resource planning systems. International journal of accounting information systems, 4(3), 205-225.

Carr, N.G. (2003), “IT doesn’t matter”, Harvard Business Review, Vol. 81 No. 5, pp. 41-9.

Castells, M. (1996). The net and the self: working notes for a critical theory of the informational society. Critique of anthropology, 16(1), 9-38.

Christensen, R., \& Knezek, G. (2001). Instruments for assessing the impact of technology in education. Computers in the Schools, 18(2-3), 5-25.

Croteau, A.-M., Venkatesh, V., Beaudry, A., \& Rabah, J. (2015). The Role of Information and Communication Technologies in University Students' Learning Experience: The Instructors' Perspective. 2015 48th Hawaii International Conference on System Sciences, 111-120. doi:10.1109/HICSS.2015.23

Delone, W. H., \& McLean, E. R. (2003). The DeLone and McLean model of information systems success: a ten-year update. Journal of management information systems, 19(4), 9-30.

Edwards, J. R., \& Bagozzi, R. P. (2000). On the nature and direction of relationships between constructs an d measures. Psychological methods, 5(2), 155.

Faiz, M. M. U., \& Al-Mutairi, M. S. (2015, September). Engineering education for a resilient society: A case study of the kingdom of Saudi Arabia. In Interactive Collaborative Learning (ICL), 2015 International Conference on (pp. 82-88). IEEE.

Gambari, A. I., \& Chike-Okoli, A. (2007). Availability and utilization of information and communication technology (ICT) facilities in higher institutions in Niger State, Nigeria. Information Technologist (The), 4(1), 34-46.

Ismail, M., Ali, A., \& Arokiasamy, L. (2012). Career Advancement of Academics at Public and Private Universities in Malaysia: Implications for Human Resource Development. Asia-Pacific Education Researcher (De La Salle University Manila), 21(3).

Jacobs, B., \& van der Ploeg, F. (2006, July). Guide to reform of higher education: A European perspective. Economic Policy, 21, 535-592. 
Krumsvik, R. J. (2008). Situated learning and teachers' digital competence. Education and Information Technologies, 13(4), 279-290.

Larsen, T. J., \& Sorebo, Ø. (2007). The Impact of Personal IT Innovativeness on Use of the Internet Among Employees at Work. In Contemporary Issues in End User Computing (pp. 29-53). IGI Global.

Mazi, A., \& Altbach, P. G. (2013). Dreams and Realities: The World-Class Idea and Saudi Arabian Higher Education. In Higher Education in Saudi Arabia (pp. 13-26). Springer Netherlands.

Mikre, F. (2011). The roles of information communication technologies in education: Review article with emphasis to the computer and internet. Ethiopian Journal of Education and Sciences, 6(2), 109-126

Neuman, Y. (2006). A theory of meaning. Information Sciences, 176(10), 1435-1449.

Nunnally, J. C. (1978). An overview of psychological measurement. In Clinical diagnosis of mental disorders (pp. 97-146). Springer US.

Okolocha, C. C., \& Nwadiani, C. O. (2015). Assessment of Utilization of ICT Resources in Teaching among Tertiary Institution Business Educators in South Nigeria. Journal of Education and Learning, 4(1), 1.

Okwudishu, C. H. (2005). Awareness and use of Information and Communication Technology (ICT) among village secondary school teachers in Aniocha South Local Government Area of Delta State. Abraka: Delta State University Unpublished B. Sc (LIS) Project.

Onasanya, S. A., Shehu, R. A., Oduware, R. O., \& Shettu, L. A. (2010). Higher institutions lecturers' attitude towards integration of ICT into teaching and research in Nigeria. Journal of Information Technology, 2, 1-10. http://dx.doi.org/10.3923/rjit.2010.1.10

Saldaña, J. (2015). The coding manual for qualitative researchers. Sage.

Smith, L., \& Abouammoh, A. (2013). Higher education in Saudi Arabia: Reforms, challenges and priorities. In Higher Education in Saudi Arabia (pp. 1-12). Springer Netherlands.

Steier, F. A. (2003). The changing nexus: Tertiary education institutions, the market place and the state. Higher Education Quarterly, 57(2), 158-180

Tallon, P.P. and Kraemer, K.L. (2007), "Fact or fiction? A sensemaking perspective on the reality behind executives' perceptions of IT business value", Journal of Management Information Systems, Vol. 24 No. 1, pp. 13-54.

Tashkandi, A. N., \& Al-Jabri, I. M. (2015). Cloud computing adoption by higher education institutions in Saudi Arabia: an exploratory study. Cluster Computing, 18(4), 15271537. 
European Journal of Technology

ISSN 2520-0712 (Online)

Vol.2, Issue 2 No.1, pp1-16, 2017

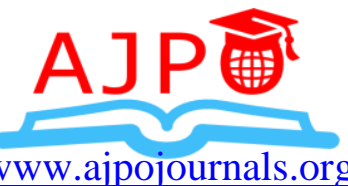

Teece, D., Pisano, G. and Shuen, A. (1997), "Dynamic capabilities and strategic management", Strategic Management Journal, Vol. 18 No. 7, pp. 509-33.

Umar, I. N., \& Hassan, A. S. A. (2015). Malaysian Teachers' Levels of ICT Integration and Its Perceived Impact on Teaching and Learning. Procedia-Social and Behavioral Sciences, 197.

UNESCO Institute for Statistics ISBN 978-92-9189-102-3 2009

Xanthidis, D., Alali, A. S., \& Koutzampasopoulou, O. (2016). Online socializing: How does it affect the information seeking behavior and the educational preferences in Saudi Arabia?. Computers in Human Behavior, 60, 425-434.

Younie, S., \& Leask, M. (2013). Teaching With Technologies: The Essential Guide: The Essential Guide. McGraw-Hill Education (UK).

Zaied, A. N. H. (2012). An integrated success model for evaluating information system in public sectors. Journal of Emerging Trends in Computing and Information Sciences, 3(6), 814-825. 